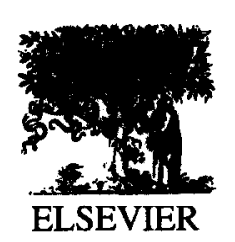

Marine Micropaleontology 29 (1997) 105-127

\title{
Benthic foraminiferal assemblages between two major extinction events: the Paleocene El Kef section, Tunisia
}

\author{
T.J. Kouwenhoven ${ }^{\mathrm{a} .}{ }^{*}, \equiv$ Speijer $^{\mathrm{b}}$, C.W.M. van Oosterhout ${ }^{\mathrm{c}}$, G.J. van der Zwaan ${ }^{\mathrm{a}}$ \\ ${ }^{a}$ Department of Geology, Faculty of Earth Sciences, Utrecht University, P.O. Box 80.021, 3508 TA Utrecht, The Netherlands \\ ${ }^{b}$ Department of Marine Geology, Earth Sciences Centre, Göteborg University, S 41381, Göteborg, Sweden \\ ${ }^{c}$ Argo Geological Consultants, Bachlaan 46, 3706 BD. Zeist, The Netherlands
}

Received 13 November 1995; accepted 18 June 1996

\begin{abstract}
The development of benthic foraminiferal assemblages from the Paleocene outcrops of the El Haria Formation near El Kef, Tunisia is discussed qualitatively and quantitatively. The aim of the study is to reconstruct the paleoenvironmental evolution between the K/Pg boundary interval and the late Paleocene event, and to compare this evolution with results from other sites along the southern Tethyan margin. Eighty-four samples, covering virtually the entire Paleocene, provide a dataset that allows detailed qualitative and multivariate analysis. The benthic foraminiferal faunas indicate a complex pattern of environmental changes during the Paleocene, marked by the succession of different benthic associations. Following the $\mathrm{K} / \mathrm{Pg}$ boundary event, community restoration was characterized by the gradual build-up of faunal diversity. Decreasing dominance and the entry of taxa common to normal marine, outer neritic to upper bathyal environments indicate the completion of the ecosystem restoration in Zone P1b. A highly diverse benthic foraminiferal assemblage persisted throughout the remainder of the early Paleocene into the earliest late Paleocene. At the P3a-P3b zonal transition relative sea-level lowering is evidenced by the sudden disappearance or decreasing abundance of deeper-water taxa (e.g. Anomalinoides affinis, A. susanaensis, Gavelinella beccariiformis). Neritic deposition continued into Zone P4, when trophic levels at the seafloor increased as indicated by the entry and increasing dominance of species such as Anomalinoides cf. aegyptiacus, Bulimina midwayensis, and $B$. strobila, which we consider to be sensitive to eutrophication. The combined effect of shallowing and the subsequent eutrophication led to the establishment of assemblages similar to late Paleocene benthic foraminiferal assemblages from Egyptian sections, some of which record the latest Paleocene extinction event. These assemblages were interpreted to be indicative of a middle neritic, highly eutrophic environment. Enhanced vertical fluxes of organic matter along the southern Tethyan margin may have resulted from intensified upwelling. This eventually led to oxygen deficiency at the seafloor. It appears that oxygen-deficient, high-productivity shelves were a common feature of the southern Tethyan margin during the latest Paleocene.
\end{abstract}

Keywords: benthic foraminifera; Paleocene; Tethys; paleoecology

\section{Introduction}

This paper reports on a qualitative and quantitative analysis of benthic foraminiferal faunas from the

${ }^{*}$ Corresponding author.
Paleocene outcrops of the El Haria Formation near El Kef, Tunisia. The paleobathymetrical evolution is reconstructed on the basis of material from eighty four samples, covering most of the Paleocene part of this section. Major faunal events mark both the $\mathrm{K} / \mathrm{Pg}$ boundary interval and the latest Paleocene. Here 